\title{
The Wunstorf Drilling Project: Coring a Global Stratigraphic Reference Section of the Oceanic Anoxic Event 2
}

\author{
by Jochen Erbacher, Jörg Mutterlose, Markus Wilmsen, Thomas Wonik, and
} the Wunstorf Drilling Scientific Party

doi:10.2204/iodp.sd.4.05.2007

\section{Introduction and Goals}

The mid-Cretaceous greenhouse world (Albian-Turonian) was characterized by high atmospheric carbon dioxide levels, much higher global temperatures than at present, and a lack of permanent ice caps at the poles (Bice et al., 2006; Huber et al., 2002; Wilson et al., 2002). A characteristic feature of this greenhouse world was the deposition of black shales during the Cenomanian / Turonian boundary interval (CTBI; Schlanger and Jenkyns, 1976; Arthur et al., 1990). These carbon-rich sediments reflect a major perturbation of the global carbon cycle, with an associated global Ocean Anoxic Event (OAE 2). Despite twenty years of research, the OAE 2 still remains critical for the understanding of some of the mechanisms driving the climate and ocean systems during this period of extreme warmth. Numerous Deep Sea Drilling Project (DSDP) and Ocean Drilling Program (ODP) sites and many on-shore sections throughout the world have recovered sediments of CTBI age. However, many of these CTBI records and OAE 2 suffer from relatively poor stratigraphic control, which greatly reduces the options to correlate paleotemperatures and carbon isotope records to micro- and macropaleontological findings on a high-resolution scale.

In order to fill this gap, an onshore drilling project, funded by the Deutsche Forschungsgemeinschaft (DFG), has been initiated. In March 2006, an 80-m-long core, covering the CTBI, has been successfully recovered near Wunstorf (20 $\mathrm{km}$ east of Hannover, Germany, Fig. 1). The easily accessible Wunstorf section is a highly expanded, middle Cenomanian to early Turonian succession exposing a thick black shale sequence. The Wunstorf drilling site was placed next to a former quarry which supplied abundant and well preserved macro- and microfossils.

The Wunstorf drilling project aims at establishing a high resolution stable isotope record for the black shale succession (OAE 2) of the CTBI and developing this into a globally applicable high resolution bio- and chemostratigraphic reference section. Disciplines involved include micropaleontology (calcareous nannofossils, planktonic foraminifera), macropaleontology (ammonites, inoceramids), stable isotopes and cyclostratigraphy mainly based on borehole logging, multi sensor core logging, and x-ray fluorescence (XRF) scanning data. The combination of geochemical, paleontological, and logging data will allow high resolution chemo- and biostratigraphy for the CTBI which may in the future serve as an international standard.

\section{The Wunstorf Core}

In northwest Germany, the sediments of the CTBI are partly represented by finely laminated, total organic carbon (TOC) rich black shales deposited under dysoxic to anoxic conditions (at Wunstorf, Misburg, and Hesseltal) in shallow basins on a wide shelf at a paleolatitude of approximately $40^{\circ} \mathrm{N}$ (e.g., Ernst et al., 1984; Wilmsen, 2003). Out of these localities Wunstorf (Fig. 1) offers the most expanded black shale sequence and, micropaleontologically, the best suited lithology. Based on field studies and archive data, the drill site was chosen about $500 \mathrm{~m}$ west of the former quarry (Fig. 1).

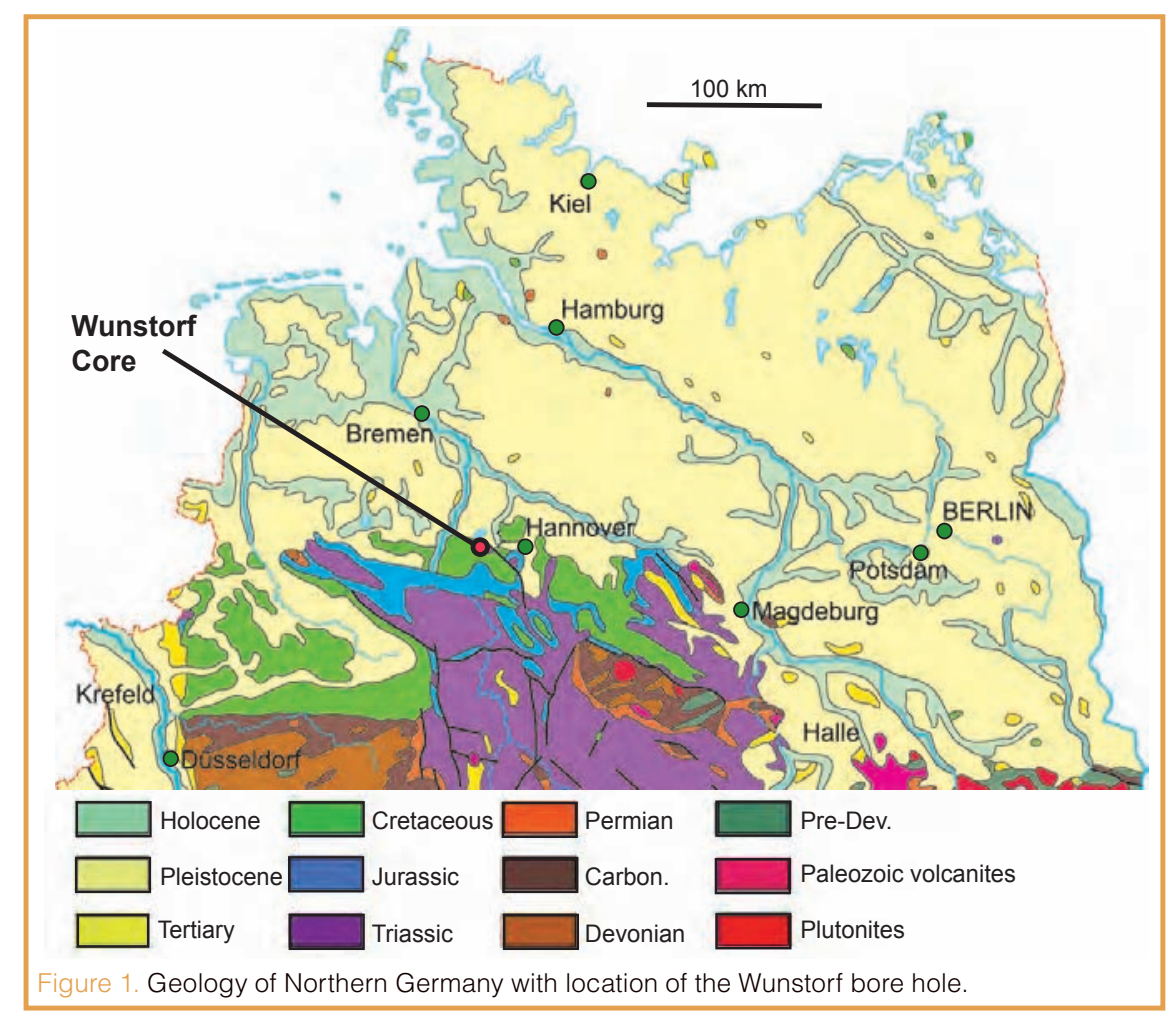




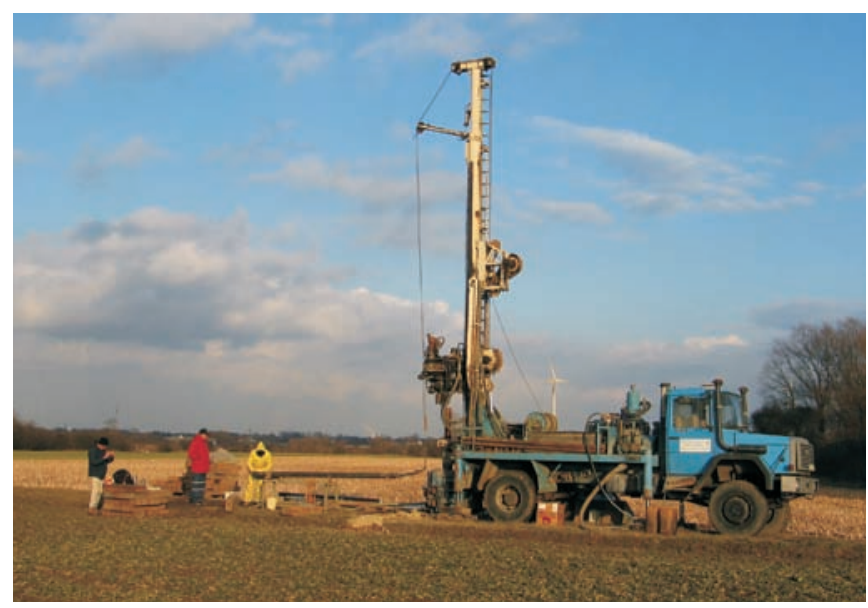

Figure 2. Coring at the Wunstorf drill site in March 2006.

The Wunstorf core was successfully drilled in early March 2006 by a truck-mounted mobile drilling system in a five-day campaign (Fig. 2). The 80-m-long core, which had excellent recovery ( $>98 \%$ ), is now stored in the Bremen Core Repository (BCR). Subsequently downhole logging has been conducted with a broad variety of logging tools-including spectral gamma ray, density, neutron porosity, geochemical logging, sonic, borehole televiewer, resistivity, induced polarization, dipmeter, susceptibility, temperature, and salinity-and will be integrated with the core logging data.

Lithologically, the core consists from bottom to top of a) $30.5 \mathrm{~m}$ of middle and upper Cenomanian limestones (80-49.5 m), b) $26.5 \mathrm{~m}$ of upper Cenomanian and early Turonian alternating marls and black shales $(49.5-23 \mathrm{~m})$, and c) $18 \mathrm{~m}$ of lower Turonian marly limestones (23-5 m). The marl to black shale succession of interval b) covers the OAE 2 sensu strictu. The OAE 2 consists of sixteen dark
TOC-rich beds up to $110 \mathrm{~cm}$ thick interbedded with pale and green marls (Fig. 3).

After the core was split into an archive and a working half, a detailed description of the whole core was made (Fig. 4). Subsequently, the core has been logged with the Multisensor Core Logger available at the BCR. After an initial sampling party in April 2006, the first studies of this core are currently underway, including stratigraphy and sedimentology (Würzburg, Berlin), stable isotope stratigraphy (Federal Institute for Geosciences and Natural Resources, BGR, Hannover; Bochum, Germany), inorganic geochemistry (University Oldenburg, Germany), organic geochemistry, x-ray fluorescence (XRF) spectroscopy scans, benthic and planktonic foraminifera (BGR Hannover, Germany), tetraether index (TEX86, Netherlands Institute for Sea Research, NIOZ, Texel, The Netherlands), dinoflagellates (Kingston, Frankfurt, Germany), and cyclicity (IfM GEOMAR, Leibniz Institute for Marine Geosciences, Kiel, Germany).

The analytical phase of the multi-disciplinary project is scheduled for the next two years. Samples will be prepared according to the disciplines involved. Following compilation of data by each group/discipline, a synthesis study is planned for the final phase of the project.

\section{First Data}

The core description and the gamma-ray data from downhole logging revealed eight to nine short-termed, potential eccentricity cycles $(100 \mathrm{ky})$ for the 26.5 -m-thick OAE 2 black shale succession, giving a duration of $850 \mathrm{ky}$ for this interval with a mean sedimentation rate of $\sim 31 \mathrm{~m} \mathrm{My}^{-1}$.

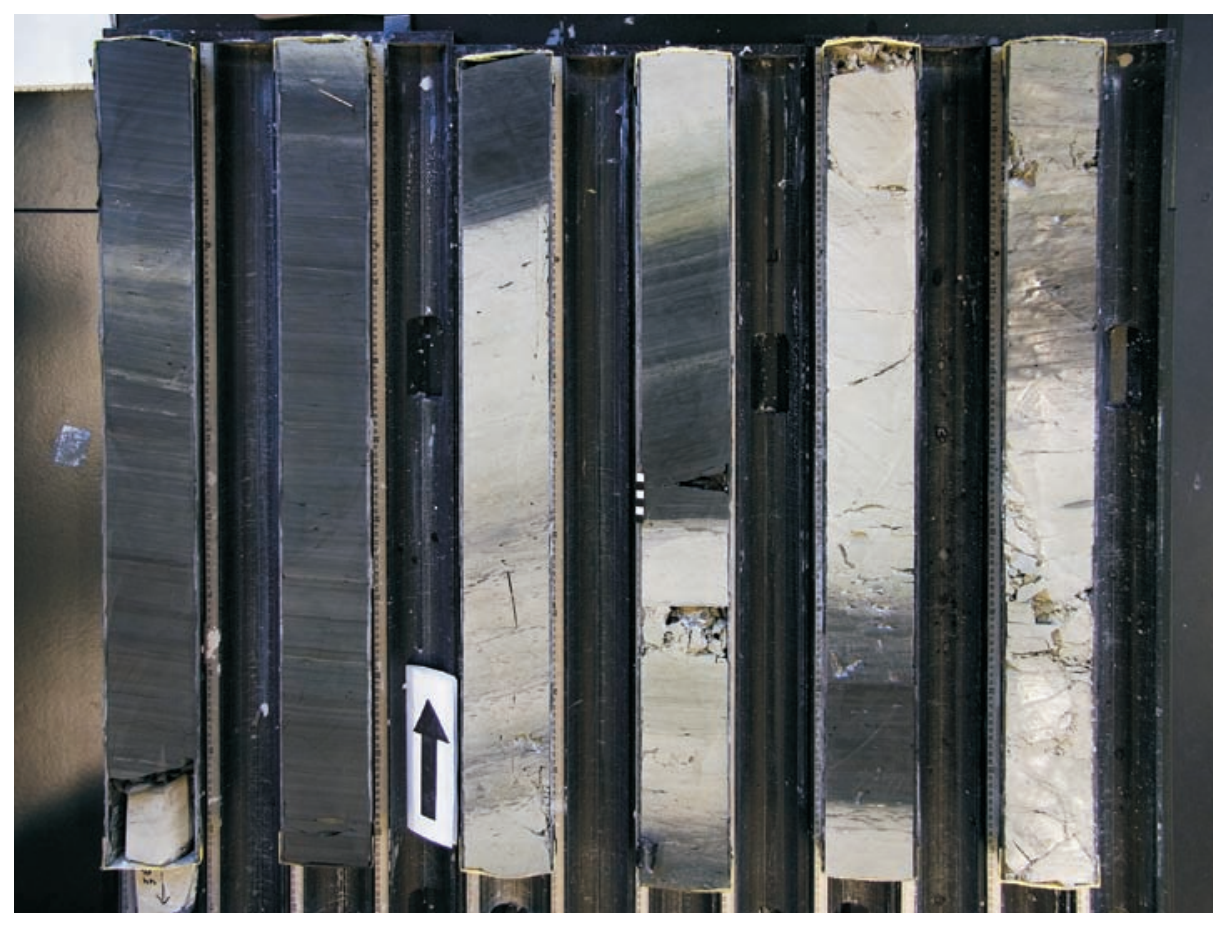

Figure 3. Meters 44 to 38 of the Wunstorf core showing dark laminated black shales.
Wunstorf Coring Scientific Drilling Party

H. Brumsack, J. Erbacher, A. Hetzel, I. Jarvis, J. Lignum, C. OstertagHenning, J. Mutterlose, J. Pross, J. Sinnighe-Damsté, S. Voigt, W. Weiß, F. Wiese and M. Wilmsen.

\section{Acknowledgements}

We would like to thank Gerold Wefer, Ursula Röhl, and the Bremen Core Repository team for the permission to use their facilities including the core storage. Oliver Friedrich and Ulia Hammer kindly helped during the sampling party. Uwe Schneider and his team from Bohr \& Brunnenbau GmbH Stedten did a great job by drilling the Wunstorf core in such a high quality. Thanks also to Ferdinand Hölscher and 
Thomas Grelle for spending a very cold day logging the borehole. The coring of the Wunstorf Core was funded by the Deutsche Forschungsgemeinschaft project number DFG Er 226/5-1.

\section{References}

Arthur, M.A., Jenkyns, H.C., Brumsack, H.-J., and Schlanger, S.O., 1990. Stratigraphy, geochemistry, and paleoceanography of organic carbonrich Cretaceous sequences. In R.N.G.B. Beaudoin (Ed.), NATO ASI Series, Ser. C: Mathematical and Physical Sciences. Kluwer, (Dordrecht), pp.75-119.

Bice, K.L., Birgel, D., Meyers, P.A., Dahle, K. A., Hinrichs, K.-U., and Norris, R.D., 2006. A multiple proxy and model study of Cretaceous upper ocean temperatures and atmospheric $\mathrm{CO}_{2}$ concentrations. Paleoceanogr., 21: PA2002, doi:10.1029/2005PA001203

Ernst, G., Wood, C.J., and Hilbrecht, H., 1984. The Cenomanian-Turonian boundary problem in NW-Germany with comments on the north-south correlation to the Regensburg-area. Bull. Geol. Soc. Denmark, 33:103-113.

Huber, B.T., Norris, R.D., and MacLeod, K.G., 2002. Deep-sea paleotemperature record of extreme warmth during the Cretaceous. Geology, 30:123-126. doi:10.1130/0091-7613(2002) $030<0123$ :DSPROE $>2.0 . \mathrm{CO} ; 2$

Schlanger, S.O. and Jenkyns, H.C., 1976. Cretaceous oceanic anoxic events: causes and consequences. Geol. Mijnb., 55:179-184.

Wilson, P.A., Norris, R.D., and Cooper, M.J., 2002. Testing the Cretaceous greenhouse hypothesis using glassy foraminiferal calcite from the core of the Turonian tropics on Demerara Rise. Geology, 30:607-610. doi:10.1130/0091-7613(2002)030<0607:TTCGHU>2.0.CO;2

Wilmsen, M., 2003. Sequence stratigraphy and palaeoceanography of the Cenomanian Stage in northern Germany. Cret. Res., 24:525-568. doi:10.1016/S0195-6671(03)00069-7

\section{Authors}

Jochen Erbacher, Federal Institute for Geosciences and Natural Resources (BGR), Stilleweg 2, 30655 Hannover, Germany, e-mail: erbacher@bgr.de.

Jörg Mutterlose, Institut für Geologie, Mineralogie und Geophysik, Ruhr-Universität-Bochum, Universitatsstr. 150, 44801 Bochum, Germany.

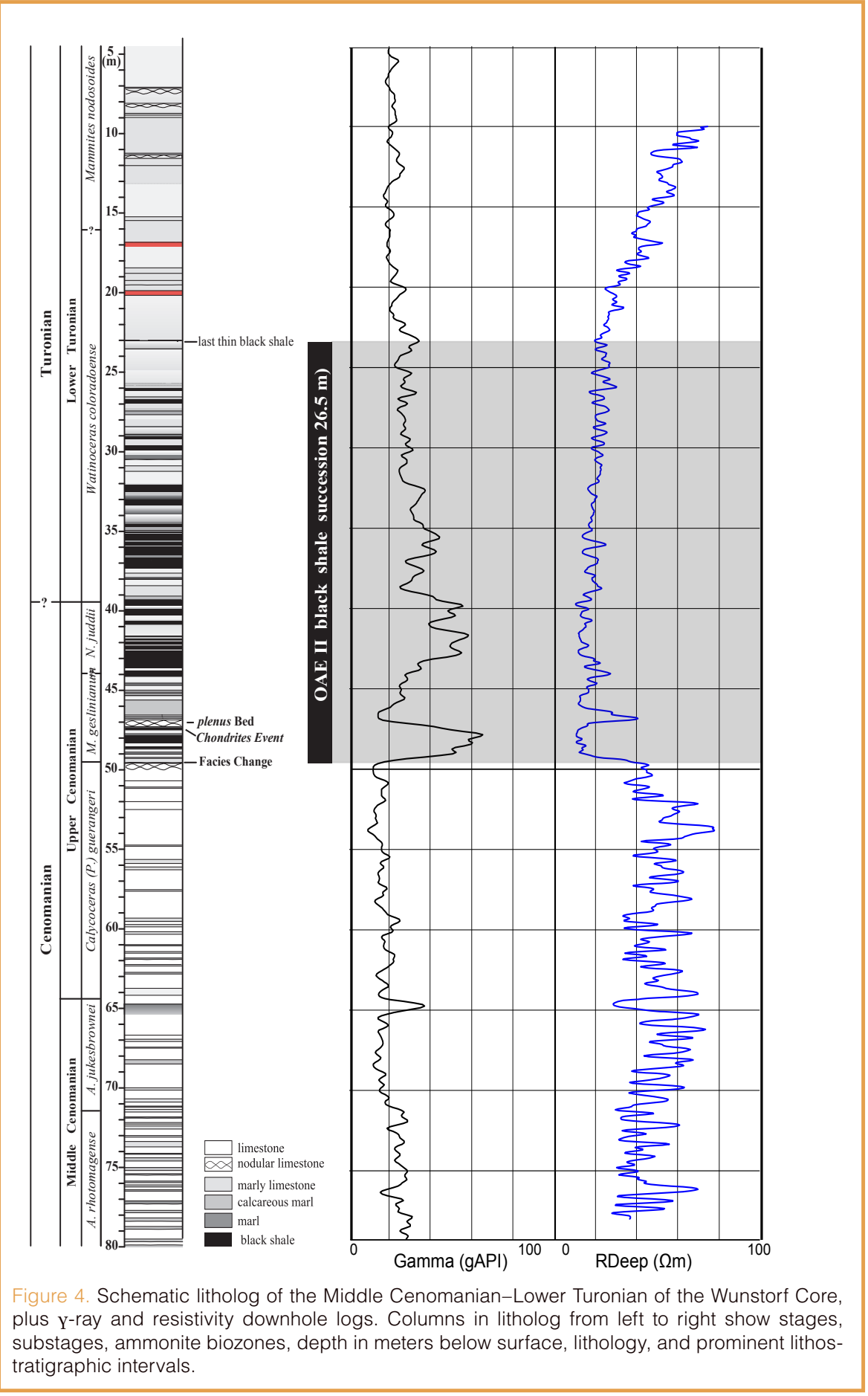

Markus Wilmsen, Institut für Palaeontologie, Universität Würzburg, Pleicherwall 1, 97070 Würzburg, Germany.

Thomas Wonik, Leibniz Institute for Applied Geosciences (GGA), Stilleweg 2, 30655 Hannover, Germany. and the Wunstorf Drilling Scientific Party.

\section{Photo and Figure Credits}

Fig. 1. Map from BGR

Fig. 2. Photo by J. Erbacher

Fig. 3. Photo by I. Jarvis 